\title{
Feeding to Produce n-3 Fatty Acid-enriched Table Eggs
}

\author{
Gordana Kralik $^{1,2}$, Manuela Grčević ${ }^{3,2}$, Danica Hanžek ${ }^{3,2}$, Polonca Margeta ${ }^{3,2}$, \\ Olivera Galovic ${ }^{4,2}$ and Zlata Kralik ${ }^{3,2}$ \\ ${ }^{1}$ Nutricin j.d.o.o. Darda, HR-31326 Darda, Croatia \\ ${ }^{2}$ Josip Juraj Strossmayer University of Osijek, Scientific Center of Excellence for \\ Personalized Health Care, HR-31000 Osijek, Croatia \\ ${ }^{3}$ Josip Juraj Strossmayer University of Osijek, Faculty of Agrobiotechnical Sciences Osijek, HR-31000 Osijek, Croatia \\ ${ }^{4}$ Josip Juraj Strossmayer University of Osijek, Department of Chemistry, HR-31000 Osijek, Croatia
}

This study aimed to modify the feed mixtures of laying hens to enrich the consumer eggs with n-3 polyunsaturated fatty acids (PUFA): $\alpha$-linolenic acid (ALA), eicosapentaenoic acid (EPA) and docosahexaenoic acid (DHA). One hundred and twenty Tetra-SL laying hens used in the study were divided into three groups of 40 laying hens arranged in five repetitions: C, control with 5\% soybean oil; E1, $0.5 \%$ fish oil $+0.5 \%$ microalgae Schizochytrium limacinum; and E2, $0.75 \%$ fish oil $+0.75 \%$ microalgae. The composition of the mixtures was balanced at the level of $17.5 \%$ raw protein and $11.81 \mathrm{MJ} / \mathrm{kg}$ metabolic energy $(\mathrm{ME})$. Feed and water were provided ad libitum, and the experiment lasted for 21 days. In this study, the different physical and chemical properties of eggs, the fatty acid profile and lipid oxidation of fat in egg yolks were analyzed. The results of the study showed that the weight of the egg yolk and that of the shell depended on the feeding treatments $(P=0.014$ and $P<0.001)$, and the weight of eggs and basic parts, as well as the thickness of the shell depended on the storage duration $(P<0.001)$. The storage time affected the $\mathrm{pH}$ of egg yolks and albumen and the reduction in Haugh units and albumen height $(P<0.001)$. Significant differences were observed in the content of ALA, DHA, $\Sigma \mathrm{n}-3$ PUFA (mg/100 g) and the n-6/n-3 PUFA ratio between the $\mathrm{C}$ and $\mathrm{E} 1 / \mathrm{E} 2$ egg groups $(P<0.001)$. The results of the study indicate that it is sufficient to use a lower level of fish oil and the microalgae Schizochytrium limacinum in hens' feed to achieve a satisfactory increase in n-3 PUFA in eggs, while maintaining optimal values of egg quality and freshness indicators.

Key words: egg quality, fish oil, n-3 PUFA, Schizochytrium limacinum, table eggs

J. Poult. Sci., 57: 138-147, 2020

\section{Introduction}

Production of designer or functional eggs enriched with n3 polyunsaturated fatty acids (n-3 PUFAs) has become popular in many countries. Nutrition in Western European countries is inadequate as meals contain higher levels of n-6 fatty acids (n-6 PUFAs) and lower levels of n-3 fatty acids, resulting in nutritional imbalances, which is associated with higher risks for certain diseases. Conventional eggs derived from laying hens fed standard feed mixture contain low

Received: June 14, 2019, Accepted: August 8, 2019

Released Online Advance Publication: August 25, 2019

Correspondence: Assoc. Prof. Zlata Kralik, Ph.D.; Josip Juraj Strossmayer University of Osijek, Faculty of Agrobiotechnical Sciences Osijek, V. Preloga 1, 31000 Osijek, Croatia. (E-mail: zlata.kralik@fazos.hr)

The Journal of Poultry Science is an Open Access journal distributed under the Creative Commons Attribution-NonCommercial-ShareAlike 4.0 International License. To view the details of this license, please visit (https:// creativecommons.org/licenses/by-nc-sa/4.0/). levels of $\alpha$-linolenic acid (ALA, C18:3n-3) and do not contain eicosapentaenoic (EPA, C20:5n-3) and docosahexaenoic acids (DHA, C22:6n-3). For balancing antioxidant activity in the body, it is recommended to consume antioxidant-rich food such as eggs enriched with n-3 PUFAs (Surai and Sparks, 2001). Studies have indicated that egg enrichment with nutricines depend on the laying hens' feed mixture composition, as n-3 PUFAs are incorporated into egg yolks (Fraeye et al., 2012; Kralik et al., 2012; Zotte et al., 2015). Poultry has limited storage capacity of n-3 PUFAs owing to their own metabolism (Kralik et al., 2015).

The definition of functional food varies, and the one used by experts from the European Commission (FuFoSE, Functional Food Science in Europe), in coordination with the International Life Science Institute (ILSI), is considered the most appropriate: "the product may be considered functional if, together with the basic nutritional effect, it has an additional effect on one or more functions of the human body, which improves the general and physical condition and/or 
reduces the risk of developing the disease." Functional food should not be in the form of tablets or capsules, but in the normal natural form of food (Siro et al., 2008).

According to Commission Regulation (EU) No. 116/2010, food is a source of omega-3 fatty acids if it contains at least $0.3 \mathrm{~g} \mathrm{ALA}$ per $100 \mathrm{~g}$ and $100 \mathrm{kcal}$ of the product and/or at least $40 \mathrm{mg} \mathrm{EPA}+$ DHA per $100 \mathrm{~g}$ and $100 \mathrm{kcal}$ of the product. Food is a high source of omega-3 fatty acids if it contains at least $0.6 \mathrm{~g}$ ALA per $100 \mathrm{~g}$ and $100 \mathrm{kcal}$ of the product and/or at least $80 \mathrm{mg}$ EPA + DHA per $100 \mathrm{~g}$ and $100 \mathrm{kcal}$ of the product.

Different feed mixtures of plant and animal origin are used in the egg enrichment process with n-3 PUFA. Flax and canola products have been successfully used to increase the ALA content (Ceylan et al., 2011; Zotte et al., 2015). Oils derived from marine organisms such as algae and fish or their combinations are used to increase the EPA and DHA content (Ao et al., 2015; Kaewsutas et al., 2016). The purpose of our research was to enrich table eggs with n-3 PUFA using fish oil and the sea algae Schizochytrium limacinum (SL). We also investigated the physicochemical properties and oxidative stability of n-3 PUFA-enriched eggs. The aim of this study was to determine which combination of fish oil and the microalgae Schizochytrium limacinum should be added to the hens' feed in order to increase the n-3 PUFA content in eggs, so that they could be marketed as an enriched product. Furthermore, the aim of the study was to determine how feeding treatments affect the quality and freshness indicators of table eggs.

\section{Materials and Methods}

\section{Laying Hens and Feed}

The study was performed on 120 Tetra-SL laying hens, divided into three groups of 40 hens (five repetitions; eight hens per repetition) that were housed in an enriched cage. Feed and water were provided ad libitum and the experiment lasted for 21 days. The composition of the feed is shown in Table 1. Three nutrition treatments used were: C, control with $5 \%$ soybean oil; E1, $0.5 \%$ fish oil $+0.5 \%$ microalgae Schizochytrium limacinum; and E2, $0.75 \%$ fish oil $+0.75 \%$ microalgae. The laying hens were in the middle of the laying cycle and were in the $47^{\text {th }}$ week of their life at the beginning of the experiment.

The nutrient content in the mixtures was determined using the following reference methods: HRN ISO 6496: 200; HRN EN ISO 5983-2: 2010; HRN EN ISO 6865: 2001, changed according to the instructions from manual FOSS Fiber Cap; HRN ISO 5984: 2004; HRN ISO 6492: 2001, and modified according to the instructions of the extraction system ANKOM XT15; RU-5.4.2-11 (internal method).

All three laying hen groups were in the same poultry house under controlled microclimatic conditions with a light length of $16 \mathrm{~h}$ per day. The eggs were collected manually, and analyses were conducted on fresh eggs. The eggs were stored for 28 days at $4{ }^{\circ} \mathrm{C}$ in the refrigerator to monitor changes in the physico-chemical properties and lipid peroxidation (thiobarbituric acid reactive substances or TBARS values).
Fatty Acid Analysis in Feed Components, Feed, and Eggs

The fatty acid profile in feed components, feed, and egg yolk was analyzed as follows: the fat of the homogenized samples was extracted using the method of Folch et al. (1957). All solvents used were of ultrapure-grade from Sigma-Aldrich (Schnelldorf, Germany). Butylated hydroxytoluene $(100 \mathrm{mg} / \mathrm{L})$ was added to the extraction mixture (chloroform: methanol, 2:1 v/v) as an antioxidant. Subsequently, fatty acid-containing lipids were transmethylated per the base-catalyzed sodium methoxide method of Christie (1982). Gas liquid chromatography was performed on a Bruker 430-GC apparatus (Bruker, Billerica, MA, USA), equipped with a FAMEWAX (RESTEK, Bellefonte, PA, USA) type capillary column $(30 \mathrm{~m} \times 0.32 \mathrm{~mm}$ internal diameter, $0.25 \mu \mathrm{m}$ film) and flame ionization detector. The characteristic operating conditions were as follows: injector temperature, $220^{\circ} \mathrm{C}$; detector temperature, $230^{\circ} \mathrm{C}$; helium flow, $25 \mathrm{ml} / \mathrm{min}$. The oven temperature was graded from 50 to $225^{\circ} \mathrm{C}$ at $6^{\circ} \mathrm{C} / \mathrm{min}$ and held for $21 \mathrm{~min}$ at $225^{\circ} \mathrm{C}$. To identify the individual fatty acids in the chromatogram, a fatty acid standard mixture (Supelco 37 Component FAME Mix, SUPELCO ${ }^{\circledR}$ Analytical, Bellefonte, PA, USA) was used. Portions of individual and total fatty acids were shown as percentage of total fatty acids in the lipids of feed components and feed, and in eggs in $\mathrm{mg} / 100 \mathrm{~g}$ edible part. Fatty acid analysis was performed for two samples of feed components (oils and microalgae), two samples of feed, and five samples of eggs per group.

Table 2 shows the average fatty acid content in the feed mixtures for laying hens ( $\%$ of total fatty acids). Table 3 shows the average fatty acid content in soybean and fish oil and in microalgae Schizochytrium limacinum (\% of total fatty acids).

\section{Physical and Chemical Properties of Eggs}

The physical and chemical properties of eggs were determined on L grade eggs. According to the current Croatian Rulebook on Egg Quality (Narodne Novine, 115/06), L grade indicates large eggs weighing 63 to $73 \mathrm{~g}$. For calculating the shape index (SI), the length and width of the eggs were measured using a sliding scale, and the shape index was calculated from these measurements according to the following formula: $\mathrm{SI}=[($ egg width $(\mathrm{mm}) /$ egg length $(\mathrm{mm})] \times$ 100. The weight of the eggs and their basic parts were measured using an electronic scale BBK 422-6 DXS, (Mettler Toledo, Greifensee, Switzerland). The shell strength was measured using the automatic device Eggshell Force Gauge Model-II (Robotmation Co., Tokyo, Japan), and the values were expressed in $\mathrm{kg} / \mathrm{cm}^{2}$. The shell thickness was measured in the middle of the egg using an electronic micrometer and the average value was used. The $\mathrm{pH}$ values of albumen and yolk were measured using a digital $\mathrm{pH}$ meter model Seven Easy (Mettler Toledo, Greifensee, Switzerland). The albumen height and Haugh unit (HU) values, as well as the yolk color, were measured using the device Egg Multi-Tester EMT-5200 (Robotmation Co.). All measurements were made on fresh eggs and eggs stored for 28 days at $4{ }^{\circ} \mathrm{C}$. Sample size was 25 eggs per group in each term of measurement, 
Table 2. Content of fatty acids in mixtures ( $\%$ of total fatty acids, $\boldsymbol{n}=\mathbf{2}$ per group*)

\begin{tabular}{|c|c|c|c|}
\hline \multirow{2}{*}{ Fatty acids } & \multicolumn{3}{|c|}{ Experimental groups } \\
\hline & $\mathrm{C}$ & E1 & E2 \\
\hline Caproic (C6:0) & 0.04 & 0.03 & 0.20 \\
\hline Caprylic (C8:0) & 0.03 & 0.02 & 0.18 \\
\hline Myristic (C14:0) & 0.10 & 0.47 & 0.45 \\
\hline Pentadecanoic (C15:0) & 0.03 & 0.11 & 0.12 \\
\hline Palmitic (C16:0) & 12.39 & 11.92 & 11.72 \\
\hline Heptadecanoic (C17:0) & 0.10 & 0.11 & 0.12 \\
\hline Stearic $(\mathrm{C} 18: 0)$ & 6.10 & 4.07 & 4.13 \\
\hline Arachidic $(\mathrm{C} 20: 0)$ & 0.58 & 0.47 & 0.54 \\
\hline Heneicosanoic (C21:0) & 0.49 & 0.34 & 0.37 \\
\hline Behenic (C22:0) & 0.51 & 0.31 & 0.36 \\
\hline Lignoceric (C23:0) & - & 0.27 & 0.32 \\
\hline$\Sigma$ SFA & 20.37 & 18.12 & 18.51 \\
\hline Myristoleic (C14:1) & 0.02 & 0.01 & 0.03 \\
\hline Palmitoleic (C16:1) & 0.13 & 0.40 & 0.26 \\
\hline cis-10-heptadecenoic (C17:1) & 0.05 & 0.08 & - \\
\hline Oleic $(\mathrm{C} 18: 1$ cis 9$)$ & 25.81 & 31.16 & 28.00 \\
\hline Elaidic (C18:1 trans 9) & 0.92 & 0.91 & 1.44 \\
\hline Eicosenoic $(\mathrm{C} 20: 1)$ & 0.24 & 0.87 & 0.41 \\
\hline ¿MUFA & 27.17 & 33.43 & 30.14 \\
\hline Linoleic (C18:2 n-6) & 47.93 & 34.85 & 36.79 \\
\hline$\Sigma$ n-6 PUFA & 47.93 & 34.85 & 36.79 \\
\hline$\alpha$-linolenic (C18:3 n-3) & 4.15 & 12.36 & 13.75 \\
\hline EPA $(C 20: 5 n-3)$ & 0.38 & 0.43 & 0.46 \\
\hline DHA (C22:6 n-3) & - & 0.81 & 0.35 \\
\hline$\sum$ n-3 PUFA & 4.53 & 13.60 & 14.56 \\
\hline n-6 PUFA /n-3 PUFA & 10.58 & 2.56 & 2.53 \\
\hline
\end{tabular}

SFA $=$ saturated fatty acids; MUFA $=$ monounsaturated fatty acids; PUFA $=$ polyunsaturated fatty acids; *the average value of the results of two sample analyses is shown.

treatments; feeding treatments: C, E1, and E2; storage, 1 and 28 days. The calculated $\mathrm{F}$ value was compared with the critical theoretical $\mathrm{F}$ value at the significance levels $P<0.05$, $P<0.01$, and $P<0.001$. The significance of differences between mean values was determined using the Fisher's least significant difference (LSD) test.

\section{Results}

The fatty acid content in the feed mixtures for laying hens is shown in Table 2. As the aim of the study was to increase the content of ALA, EPA, and DHA or $\Sigma$ n-3 PUFA in eggs, E1 and E2 were modified with respect to the control group using fish oil and microalgae. Analysis of the n-3 PUFA profile showed that the experimental mixtures E1 and E2 contained higher levels of ALA $(12.36 \%$ and $13.75 \%$, respectively), EPA ( $0.43 \%$ and $0.46 \%$, respectively) in relation to control mixture (4.15\% ALA and $0.38 \%$ EPA), and also DHA (0.31\% and $0.35 \%$, respectively), which was not present in the control feed mixture. The n-6/n-3 PUFA ratio in the experimental mixtures E1 (2.56) and E2 (2.53) was significantly lower than that in the control mixture (10.57).
The fatty acid profile of oils and microalgae is shown in Table 3. Soybean oil has a higher content of $\Sigma$ SFA (saturated fatty acids) and $\Sigma \mathrm{n}-6$ PUFA, and lower content of ¿MUFA (monounsaturated fatty acids) and $\Sigma$ n-3 PUFA than fish oil. The microalgae $S$. limacinum has considerably high proportion of DHA $(21.33 \%)$.

Table 4 shows the quality of L class eggs, in terms of relative and absolute indicators such as SI (\%), egg weight (g), albumen weight $(\mathrm{g})$, yolk weight $(\mathrm{g})$, and shell weight $(\mathrm{g})$. Feeding treatments and storage time affected the yolk weight and weight of the shell $(P=0.014$ and $P<0.001)$, although their interaction was not statistically significant $(P>0.05)$. Diffusion between the egg yolk and albumen affects the changes in the weight of the base parts. During the 28 days of egg storage in the refrigerator, the egg weight decreased in the E1 and E2 group compared to that in the control group $(P<0.001)$. The storage duration reduced egg shell strength $(P=0.032)$, as well as shell thickness $(P<$ $0.001)$.

Table 5 shows the egg yolk color and egg freshness indicators. Yolk color depended on feeding treatment, storage 
Table 3. Content of fatty acids in soybean and fish oil and microalgae Schizochytrium limacinum (\% of total fatty acids; $n=2$ per sample*)

\begin{tabular}{|c|c|c|c|}
\hline Fatty acids & Soybean oil & Fish oil & $\begin{array}{c}\text { Microalgae } \\
\text { Schizochytrium } \\
\text { limacinum }\end{array}$ \\
\hline Lauric (C12:0) & 0.00 & 0.00 & 0.19 \\
\hline Myristic (C14:0) & 0.00 & 2.15 & 5.62 \\
\hline Pentadecanoic (C15:0) & 0.00 & 0.00 & 1.90 \\
\hline Palmitic (C16:0) & 10.31 & 9.40 & 57.18 \\
\hline Heptadecanoic (C17:0) & 0.00 & 0.00 & 0.58 \\
\hline Stearic $(\mathrm{C} 18: 0)$ & 6.12 & 2.87 & 2.24 \\
\hline Heneicosanoic (C21:0) & 0.00 & 1.13 & 0.00 \\
\hline Arachidic (C20:0) & 0.00 & 0.00 & 0.37 \\
\hline Behenic (C22:0) & 0.00 & 0.00 & 0.20 \\
\hline Tricosanoic (C23:0) & 0.00 & 0.00 & 0.16 \\
\hline Lignoceric (C24:0) & 0.00 & 0.00 & 0.14 \\
\hline$\Sigma$ SFA & 16.44 & 15.54 & 68.58 \\
\hline Palmitoleic (C16:1) & 0.00 & 2.78 & 0.31 \\
\hline cis-10-heptadecenoic (C17:1) & 0.00 & 0.00 & 0.05 \\
\hline Oleic $(\mathrm{C} 18: 1$ cis 9$)$ & 26.89 & 40.25 & 3.45 \\
\hline Elaidic (C18:1 trans 9) & 1.56 & 3.15 & 0.34 \\
\hline Eicosenoic (C20:1) & 0.00 & 4.82 & 0.00 \\
\hline Erucic $(\mathrm{C} 22: 1)$ & 0.00 & 3.19 & 0.00 \\
\hline Nervonic (C24:1) & 0.00 & 0.00 & 0.16 \\
\hline$\Sigma$ MUFA & 28.45 & 54.18 & 4.31 \\
\hline Linoleic (C18:2 n-6) & 49.42 & 14.41 & 2.97 \\
\hline Eicosadienoic (C20:2 n-6) & 0.00 & 0.00 & 0.13 \\
\hline Arachidonic (C20:4 n-6) & 0.00 & 0.00 & 0.79 \\
\hline इn-6 PUFA & 49.42 & 14.41 & 3.89 \\
\hline$\alpha$-linolenic (C18:3 n-3) & 5.69 & 6.33 & 1.47 \\
\hline Eicosatrienoic (C:20:3 n-3) & 0.00 & 0.51 & 0.00 \\
\hline EPA (C20:5 n-3) & 0.00 & 3.81 & 0.43 \\
\hline DHA (C22:6 n-3) & 0.00 & 5.23 & 21.33 \\
\hline ¿n-3 PUFA & 5.69 & 15.88 & 23.23 \\
\hline n-6 PUFA /n-3 PUFA & 8.69 & 0.91 & 0.17 \\
\hline
\end{tabular}

$\mathrm{SFA}=$ saturated fatty acids; MUFA $=$ monounsaturated fatty acids; PUFA $=$ polyunsaturated fatty acids; *the average value of the results of two sample analyses is shown.

duration, and their interactions $(P<0.001)$. Yolk color is an important indicator of industrial egg processing. HU also depended on storage duration as well as albumen height $(P<$ $0.001)$. The albumen $\mathrm{pH}$ was affected by feeding treatments, storage duration, and their interaction $(P<0.001)$; the $\mathrm{pH}$ of the egg yolk was affected by feeding treatments and storage time $(P<0.001)$. Degradation of the yolk and albumen affected the $\mathrm{pH}$, which was affected by feeding treatments $(P$ $<0.001)$ and egg storage time in the refrigerator $(P<0.01)$. Statistical analysis showed that HU depended on the time of egg storage in the refrigerator $(P<0.001)$.

Table 6 shows the levels of SFA, MUFA, n-6 PUFA, n-3 PUFA (mg/100 g of egg), and n-6/n-3 PUFA in the eggs of control and experimental groups. Statistically significant differences $(P<0.05)$ were observed in the content of saturated fatty acids such as pentadecanoic (C15:0, $P=0.008)$, heneicosanoic $(\mathrm{C} 21: 0, P=0.002)$, and $\sum \operatorname{SFA}(P=0.006)$. High statistically significant differences $(P<0.001)$ were observed in the content of stearic (C18:0) fatty acid, oleic acid (C18:1 cis 9) and $\mathrm{M}$ MUFA content between the control and experimental groups. Among the n-6 PUFA, statistically significant differences $(P<0.01)$ were observed for linoleic fatty acid and $\Sigma$ n-6 PUFA, and highly significant differences $(P<$ $0.001)$ were observed for $\gamma$-linolenic $(\mathrm{C} 18: 3 \mathrm{n}-6)$ and arachidonic fatty acids. Statistically significant differences $(P<$ $0.001)$ were observed in the contents of $\alpha$-linolenic acid (C18:3 n-3), docosahexaenoic acid (C22:6 n-3), and $\Sigma \mathrm{n}-3$ PUFA. The n-6/n-3 PUFA ratio was significantly lower in E1 and E2 than in the control group (4.23 and 4.72 for E1 and E2, respectively, versus 10.65 for the control; $P<0.001$ ).

$\Sigma$ n-3 PUFA was higher in the experimental groups E1 and E2 than in the control group by 2.03- and 2.0-fold. ALA was 2.5 and 2.24 times higher, and DHA was 1.69 and 1.55 times higher in the experimental groups than in the control group. 
Table 4. Quality of eggs and egg shell ( $n=25$ per group)

\begin{tabular}{|c|c|c|c|c|c|c|c|c|}
\hline Factors & Groups & $\begin{array}{c}\text { Shape } \\
\text { index } \\
(\%)\end{array}$ & $\begin{array}{l}\text { Egg } \\
\text { weight } \\
(\mathrm{g})\end{array}$ & $\begin{array}{c}\text { Albumen } \\
\text { weight } \\
\text { (g) }\end{array}$ & $\begin{array}{c}\text { Yolk } \\
\text { weight } \\
(\mathrm{g})\end{array}$ & $\begin{array}{c}\text { Egg } \\
\text { shell } \\
\text { weight } \\
(\mathrm{g})\end{array}$ & $\begin{array}{c}\text { Egg } \\
\text { shell } \\
\text { strength } \\
\left(\mathrm{kg} / \mathrm{cm}^{2}\right)\end{array}$ & $\begin{array}{c}\text { Egg } \\
\text { shell } \\
\text { thickness } \\
(\mathrm{mm})\end{array}$ \\
\hline \multirow{3}{*}{$\begin{array}{l}\text { Feeding } \\
\text { treatment } \\
(\mathrm{FT})\end{array}$} & $\mathrm{C}$ & 76.54 & 68.85 & 41.12 & $16.71^{\mathrm{b}}$ & $9.01^{\mathrm{a}}$ & 3.09 & 0.442 \\
\hline & E1 & 75.83 & 66.90 & 40.96 & $16.88^{\mathrm{b}}$ & $9.00^{\mathrm{a}}$ & 2.90 & 0.414 \\
\hline & E2 & 76.17 & 66.85 & 41.14 & $17.40^{\mathrm{a}}$ & $8.34^{\mathrm{b}}$ & 2.85 & 0.401 \\
\hline \multirow{2}{*}{$\begin{array}{l}\text { Storage } \\
\text { time (ST) }\end{array}$} & Fresh & 76.17 & $68.03^{\mathrm{a}}$ & $42.48^{\mathrm{a}}$ & $16.63^{\mathrm{b}}$ & $8.96^{\mathrm{a}}$ & $3.04^{\mathrm{a}}$ & $0.440^{\mathrm{a}}$ \\
\hline & Storage & 76.19 & $65.66^{\mathrm{b}}$ & $39.67^{\mathrm{b}}$ & $17.36^{\mathrm{a}}$ & $8.62^{\mathrm{b}}$ & $2.86^{\mathrm{b}}$ & $0.385^{\mathrm{b}}$ \\
\hline \multirow{6}{*}{ Interaction } & $\mathrm{C} \times$ Fresh & 76.31 & 68.49 & $43.28^{\mathrm{a}}$ & 16.15 & 9.05 & 3.12 & $0.431^{\mathrm{ab}}$ \\
\hline & E1 $\times$ Fresh & 75.94 & 67.69 & $41.82^{\mathrm{b}}$ & 16.68 & 9.18 & 2.98 & $0.447^{\mathrm{a}}$ \\
\hline & E2 $\times$ Fresh & 76.33 & 68.06 & $42.34^{\mathrm{ab}}$ & 17.08 & 8.64 & 3.02 & $0.442^{\mathrm{a}}$ \\
\hline & $\mathrm{C} \times$ Storage & 76.78 & 65.22 & $38.96^{\mathrm{c}}$ & 17.28 & 8.98 & 3.06 & $0.413^{\mathrm{b}}$ \\
\hline & E1 $\times$ Storage & 76.41 & 66.02 & $40.10^{\mathrm{c}}$ & 17.09 & 8.83 & 2.82 & $0.381^{\mathrm{c}}$ \\
\hline & E $2 \times$ Storage & 75.32 & 65.74 & $39.95^{\mathrm{c}}$ & 17.73 & 8.05 & 2.69 & $0.360^{\mathrm{d}}$ \\
\hline \multicolumn{9}{|l|}{$P$ value } \\
\hline FT & & 0.662 & 0.994 & 0.922 & 0.014 & $<0.001$ & 0.054 & 0.083 \\
\hline ST & & 0.969 & $<0.001$ & $<0.001$ & $<0.001$ & $<0.001$ & 0.032 & $<0.001$ \\
\hline Interaction & & 0.558 & 0.296 & 0.027 & 0.329 & 0.259 & 0.427 & $<0.001$ \\
\hline
\end{tabular}

C, control, $5 \%$ soybean oil; E1, $0.5 \%$ fish oil $+0.5 \%$ microalgae; E2, $0.75 \%$ fish oil $+0.75 \%$ microalgae

Table 5. Egg yolk color and indicators of egg freshness $(n=25$ per group)

\begin{tabular}{|c|c|c|c|c|c|c|}
\hline Factors & Groups & $\begin{array}{l}\text { Yolk } \\
\text { color }\end{array}$ & $\mathrm{HU}$ & $\begin{array}{c}\text { Albumen } \\
\text { height } \\
(\mathrm{mm})\end{array}$ & $\begin{array}{c}\text { Albumen } \\
\mathrm{pH}\end{array}$ & $\begin{array}{c}\text { Yolk } \\
\mathrm{pH}\end{array}$ \\
\hline \multirow{3}{*}{$\begin{array}{l}\text { Feeding } \\
\text { treatment } \\
\text { (FT) }\end{array}$} & $\mathrm{C}$ & $13.20^{\mathrm{a}}$ & 78.92 & 6.51 & $8.33^{\mathrm{b}}$ & $6.14^{\mathrm{b}}$ \\
\hline & E1 & $12.10^{\mathrm{b}}$ & 76.63 & 6.44 & $8.62^{\mathrm{a}}$ & $6.23^{\mathrm{a}}$ \\
\hline & E2 & $13.22^{\mathrm{a}}$ & 75.21 & 6.13 & $8.63^{\mathrm{a}}$ & $6.23^{\mathrm{a}}$ \\
\hline \multirow{2}{*}{$\begin{array}{l}\text { Storage } \\
\text { time (ST) }\end{array}$} & Fresh & $12.45^{\mathrm{b}}$ & $79.79^{\mathrm{a}}$ & $6.80^{\mathrm{a}}$ & $8.36^{\mathrm{b}}$ & $6.09^{\mathrm{b}}$ \\
\hline & Storage & $13.26^{\mathrm{a}}$ & $74.05^{\mathrm{b}}$ & $5.92^{\mathrm{b}}$ & $8.68^{\mathrm{a}}$ & $6.31^{\mathrm{a}}$ \\
\hline \multirow{6}{*}{ Interaction } & $\mathrm{C} \times$ Fresh & $13.20^{\mathrm{bc}}$ & 82.21 & 7.00 & $8.26^{\mathrm{c}}$ & 6.05 \\
\hline & E1 $\times$ Fresh & $13.00^{\mathrm{c}}$ & 78.85 & 8.84 & $8.42^{\mathrm{b}}$ & 6.09 \\
\hline & E2 $\times$ Fresh & $11.16^{\mathrm{d}}$ & 78.32 & 6.56 & $8.41^{\mathrm{b}}$ & 6.12 \\
\hline & $\mathrm{C} \times$ Storage & $13.32^{\mathrm{ab}}$ & 75.64 & 6.01 & $8.40^{\mathrm{b}}$ & 6.24 \\
\hline & E1 $\times$ Storage & $13.44^{\mathrm{a}}$ & 74.40 & 6.05 & $8.84^{\mathrm{a}}$ & 6.36 \\
\hline & E2 $\times$ Storage & $13.04^{\mathrm{c}}$ & 72.11 & 5.70 & $8.83^{\mathrm{a}}$ & 6.34 \\
\hline \multicolumn{7}{|l|}{$P$ value } \\
\hline FT & & $<0.001$ & 0.071 & 0.176 & $<0.001$ & $<0.001$ \\
\hline ST & & $<0.001$ & $<0.001$ & $<0.001$ & $<0.001$ & $<0.001$ \\
\hline Interaction & & $<0.001$ & 0.782 & 0.892 & $<0.001$ & 0.067 \\
\hline
\end{tabular}

C, control, $5 \%$ soybean oil; E1, $0.5 \%$ fish oil $+0.5 \%$ microalgae; E2, $0.75 \%$ fish oil $+0.75 \%$ microalgae

The n-6/n-3 PUFA ratio was reduced from 10.65 in control group to 4.23 and 4.72 in the experimental groups E1 and E2, respectively $(P<0.001)$.

Table 7 shows the differences in TBARS values between and within the examined groups of fresh and stored eggs. TBARS values are expressed as $\mu \mathrm{g}$ MDA/g of egg yolk. The TBARS values did not vary significantly between the groups in the analysis of fresh eggs $(\mathrm{C}=1.453 \mu \mathrm{g} \mathrm{MDA} / \mathrm{g} ; \mathrm{E} 1=$ $1.455 \mu \mathrm{g} \mathrm{MDA} / \mathrm{g}$, and $\mathrm{E} 2=1.508 \mu \mathrm{g} \mathrm{MDA} / \mathrm{g} ; P=0.929)$. However, a statistically significant difference $(P=0.020)$ was observed between the control $(1.397 \mu \mathrm{g}$ MDA/g) and E1 $(1.745 \mu \mathrm{g} \mathrm{MDA} / \mathrm{g})$ and E2 $(1.829 \mu \mathrm{g} \mathrm{MDA} / \mathrm{g})$ groups of stored eggs. Within the same group, a statistically significant difference in TBARS values was observed in the yolk analysis of the E1 group, where oxidation was more intense after storage (fresh eggs $=1.455 \mu \mathrm{g} \mathrm{MDA} / \mathrm{g}$ versus stored eggs $=1.745 \mu \mathrm{g} \mathrm{MDA} / \mathrm{g} ; P=0.044)$. For groups $\mathrm{C}$ and $\mathrm{E} 2$, the difference in TBARS values within groups was not recorded $(P>0.05)$. Analysis of the results showed that oxidation occurs more rapidly in the eggs of the modified 
Table 6. Content of fatty acids in $\mathbf{m g} / \mathbf{1 0 0} \mathrm{g}$ of edible part of eggs ( $n=5$ per group)

\begin{tabular}{|c|c|c|c|c|}
\hline \multirow{2}{*}{ Fatty acid } & \multicolumn{3}{|c|}{${ }^{1}$ Feeding treatments/Statistical parameter $(\bar{x})$} & \multirow[t]{2}{*}{$P$ value } \\
\hline & $\mathrm{C}$ & E1 & E2 & \\
\hline Myristic (C14:0) & $15.87 \pm 1.19$ & $17.41 \pm 2.05$ & $16.41 \pm 1.99$ & 0.414 \\
\hline Pentadecanoic (C15:0) & $2.41 \pm 2.20^{\mathrm{ab}}$ & $0.00 \pm 0.00^{\mathrm{b}}$ & $4.97 \pm 2.78^{\mathrm{a}}$ & 0.008 \\
\hline Palmitic (C16:0) & $1488.69 \pm 26.32$ & $1413.97 \pm 55.77$ & $1481.60 \pm 70.34$ & 0.092 \\
\hline Heptadecanoic (C17:0) & $16.87 \pm 0.63$ & $16.68 \pm 1.88$ & $19.21 \pm 2.88$ & 0.132 \\
\hline Stearic $(\mathrm{C} 18: 0)$ & $683.91 \pm 36.33^{\mathrm{a}}$ & $622.25 \pm 15.07^{\mathrm{b}}$ & $604.32 \pm 23.67^{\mathrm{b}}$ & $<0.001$ \\
\hline Heneicosanoic $(\mathrm{C} 21: 0)$ & $14.41 \pm 3.35^{\mathrm{a}}$ & $11.29 \pm 1.23^{\mathrm{b}}$ & $12.22 \pm 1.51^{\mathrm{b}}$ & 0.002 \\
\hline$\Sigma$ SFA & $2225.17 \pm 48.17^{\mathrm{a}}$ & $2081.61 \pm 56.07^{\mathrm{b}}$ & $2138.73 \pm 65.48^{\mathrm{b}}$ & 0.006 \\
\hline Palmitoleic (C16:1) & $86.96 \pm 4.64$ & $96.07 \pm 8.38$ & $97.87 \pm 22.04$ & 0.436 \\
\hline cis-10-heptadecenoic (C17:1) & $8.33 \pm 0.57$ & $8.15 \pm 4.98$ & $6.27 \pm 6.12$ & 0.737 \\
\hline Oleic $(\mathrm{C} 18: 1$ cis 9$)$ & $2477.71 \pm 112.86^{\mathrm{b}}$ & $2767.43 \pm 70.66^{\mathrm{a}}$ & $2585.46 \pm 71.36^{\mathrm{b}}$ & $<0.001$ \\
\hline Elaidic (C18:1 trans 9) & $85.55 \pm 22.21$ & $106.14 \pm 1.81$ & $96.00 \pm 19.07$ & 0.199 \\
\hline Cis-11-eicosenoic (C20:1) & $13.73 \pm 1.57$ & $13.81 \pm 0.94$ & $12.79 \pm 0.96$ & 0.358 \\
\hline$\Sigma$ MUFA & $2672.31 \pm 101.83^{\mathrm{b}}$ & $2991.62 \pm 77.91^{\mathrm{a}}$ & $2798.41 \pm 103.97^{\mathrm{b}}$ & $<0.001$ \\
\hline Linoleic (C18:2 n-6) & $1624.13 \pm 136.04^{\mathrm{a}}$ & $1321.01 \pm 99.22^{\mathrm{b}}$ & $1441.68 \pm 107.49^{\mathrm{b}}$ & 0.004 \\
\hline$\gamma$-linolenic $(18: 3 \mathrm{n}-6)$ & $8.49 \pm 0.59^{\mathrm{a}}$ & $1.79 \pm 4.01^{\mathrm{b}}$ & $8.23 \pm 1.49^{\mathrm{b}}$ & $<0.001$ \\
\hline Eicosadienoic (C20:2 n-6) & $12.24 \pm 0.23$ & $9.07 \pm 5.30$ & $12.72 \pm 2.85$ & 0.237 \\
\hline Arachidonic $(20: 4 \mathrm{n}-6)$ & $137.80 \pm 5.05^{\mathrm{a}}$ & $102.43 \pm 8.27^{\mathrm{b}}$ & $112.27 \pm 16.63^{b}$ & $<0.001$ \\
\hline इn-6 PUFA & $1782.67 \pm 140.09^{\mathrm{b}}$ & $1434.30 \pm 108.38^{\mathrm{b}}$ & $1574.92 \pm 125.77^{\mathrm{b}}$ & 0.003 \\
\hline$\alpha$-linolenic $(\mathrm{C} 18: 3 \mathrm{n}-3)$ & $71.73 \pm 10.03^{\mathrm{b}}$ & $177.33 \pm 17.65^{\mathrm{a}}$ & $161.00 \pm 18.92^{\mathrm{a}}$ & $<0.001$ \\
\hline Eicosapentaenoic (C20:5 n-3) & $5.70 \pm 0.44$ & $10.37 \pm 1.04$ & $7.88 \pm 4.54$ & 0.054 \\
\hline Docosahexaenoic (C22:6 n-3) & $89.90 \pm 4.42^{\mathrm{c}}$ & $152.25 \pm 12.11^{\mathrm{b}}$ & $166.55 \pm 9.19^{\mathrm{a}}$ & $<0.001$ \\
\hline$\sum$ n-3 PUFA & $167.33 \pm 10.72^{\mathrm{b}}$ & $339.96 \pm 25.48^{\mathrm{a}}$ & $335.43 \pm 18.70^{\mathrm{a}}$ & $<0.001$ \\
\hline n-6/n-3 PUFA & $10.65 \pm 0.52^{\mathrm{a}}$ & $4.23 \pm 0.38^{\mathrm{b}}$ & $4.72 \pm 0.60^{\mathrm{b}}$ & $<0.001$ \\
\hline
\end{tabular}

C, control, $5 \%$ soybean oil; E1, $0.5 \%$ fish oil $+0.5 \%$ microalgae; $\mathrm{E} 2,0.75 \%$ fish oil $+0.75 \%$ microalgae

Table 7. TBARS values ( $\mu$ g MDA/g of egg yolk; $\boldsymbol{n}=\mathbf{6}$ per group)

\begin{tabular}{lccc}
\hline \hline $\begin{array}{c}\text { Group - feeding } \\
\text { treatment (FT) }\end{array}$ & $\begin{array}{c}\text { Fresh eggs } \\
\text { TBARS }(\bar{x} \pm \mathrm{s} \bar{x})\end{array}$ & $\begin{array}{c}\text { Stored eggs } \\
\text { TBARS }(\bar{x} \pm \mathrm{s} \bar{x})\end{array}$ & P value \\
\hline $\mathrm{C}$ & $1.453 \pm 0.17$ & $1.397 \pm 0.2^{\mathrm{b}}$ & 0,669 \\
$\mathrm{E} 1$ & $1.455 \pm 0.16^{\mathrm{B}}$ & $1.745 \pm 0.21^{\mathrm{aA}}$ & 0,044 \\
$\mathrm{E} 2$ & $1.508 \pm 0.37$ & $1.829 \pm 0.22^{\mathrm{a}}$ & 0,136 \\
\hline P value & 0,929 & 0,020 & \\
\hline C, control, 5\% soybean oil; E1, 0.5\% fish oil + 0.5\% microalgae; E2, $0.75 \%$ fish oil \\
+ 0.75\% microalgae; FT, feeding treatment; ST, storage time \\
a,b letters above numbers represent the difference between the values shown in the \\
columns \\
A, B letters above numbers represent the difference between the values shown in the \\
rows
\end{tabular}

composition (E1 and E2) than in conventional eggs (C). Thus, we believe that oxidation is faster because of the higher content of unsaturated fatty acids in the eggs of the experimental groups, which are more susceptible to oxidation.

\section{Discussion}

In this study, the aim was to determine the increase of $n-3$ PUFA content in table eggs using specially designed feeding treatments $(\mathrm{C}=5 \%$ soybean oil; $\mathrm{E} 1=0.5 \%$ fish oil $+0.5 \%$ microalgae Schizochytrium limacinum (SL) and E2 $=0.75 \%$ fish oil $+0.75 \%$ microalgae). The aim was also to determine the effect of feeding treatments and storage time on egg quality and freshness. The results show that by using a feeding treatment with a lower level of fish oil and the microalgae Schizochytrium limacinum resulted in an increase in n-3 PUFA in eggs that meets the prescribed n-3 PUFA content for eggs that can be declared enriched. Furthermore, the results of the study show that eggs from feeding treatments with the addition of the microalgae Schizochytrium limacinum have a more intense yolk color, which is a very 
important indicator of egg quality for consumers.. Egg quality is influenced by various factors, which can be divided into genetic and non-genetic factors (Shin et al., 2012; Wolc et al., 2012). Non-genetic factors include feeding, hens' rearing system, and egg storage conditions. The most important storage factors are temperature, storage time, relative air humidity, and the amount of $\mathrm{CO}_{2}$ in the room where the eggs are stored (Silversides and Scott, 2001, Samli et al., 2005; Shin et al., 2012). Lee et al. (2016) indicated that during storage, certain egg quality indicators gradually decrease (egg weight, shell weight, HU, albumen height and viscosity, and shell thickness) while some increase ( $\mathrm{pH}$ of yolk and albumen, yolk color, and shell density). In our study, we have also determined the trend in the changes of some of these indicators.

For all the listed indicators, the values changed more rapidly when the storage temperature was higher (Lee et al., 2016). Although the SI is not considered an egg quality factor, it can affect the thickness and strength of the shell. Therefore, this indicator is important for egg quality assessment (Ikegwu et al., 2016). According to Duman et al. (2016), eggshell index can be classified into three classes: sharp eggs (shape index lower than 72), normal or standard eggs (shape index from 72 to 76), and round eggs (shape index higher than 76). These authors observed a negative correlation between the SI and shell thickness and strength for eggs with SI below 72, while a positive correlation was observed for standard eggs. In our study, we used eggs with SI characteristic for standard eggs, which also had optimal values for shell strength and thickness $\left(\mathrm{C}=3.09 \mathrm{~kg} / \mathrm{cm}^{2}\right.$ and $0.442 \mathrm{~mm} ; \mathrm{E} 1=2.90 \mathrm{~kg} / \mathrm{cm}^{2}$ and $0.414 \mathrm{~mm}$, and $\mathrm{E} 2=2.85$ $\mathrm{kg} / \mathrm{cm}^{2}$ and $0.401 \mathrm{~mm}$ ). The shell thickness and strength values in our groups were higher than those of standard eggs mentioned by the aforementioned authors $\left(2.69 \mathrm{~kg} / \mathrm{cm}^{2}\right.$ and $0.349 \mathrm{~mm}$ ). Kralik et al. (2005) observed that addition of the n-3 PUFA-rich oil to the laying hens' feed increased the weight of the egg yolk, as well as the thickness and weight of the shell. Their results are in partial agreement with those of ours, as we have also recorded higher yolk weight in the group of hens that consumed feed supplemented with fish oil. In our study, the shell quality indicators were significantly influenced by storage time (shell strength $P=0.032$ and shell thickness $P<0.001$ ) and the interaction of storage time and feeding treatment (shell thickness $P<0.001$ ).

Several studies have reported that storage conditions (storage time and temperature) primarily affect internal egg quality (HU, albumen height, yolk color, and $\mathrm{pH}$ of albumen and yolk), whereas in most cases storage conditions do not affect egg shell quality (Silversides and Scott, 2001; Lee et al., 2016). However, Samli et al. (2005) observed that storage time has no statistically significant effect on shell thickness $(P=0.467)$, while storage temperature combined with storage time significantly affected shell thickness $(P=$ 0.041).

In a study on the effect of the level and type of fish oil in the feed for laying hens on the content and profile of fatty acids in yolks, Cachaldora et al. (2006) observed that higher levels of fish oil ( $60 \mathrm{~g} / \mathrm{kg}$ in the feed for laying hens) reduced the shell thickness. In agreement with the above results, we showed that the use of fish oil in hen feed, and in combination with egg storage time, significantly affected the thickness of the shell in our study $(P<0.001)$. Analysis of the results of this study indicated that the shell strength and thickness in the eggs of the E1 and E2 experimental groups are lower than those of the control group $(P>0.05)$. Studies have shown that the addition of different seeds and oils to hen feed for increasing the omega-3 fatty acid content affects the shell quality (reduced strength and thickness). Phytic acid, found in many grains, soybean, and legumes, can disrupt the absorption of various minerals, including calcium, which is required for the calcification of the shell, thereby reducing its quality. Based on the factors mentioned above, we assumed that the effect of the interaction of feeding treatment and storage time on eggshell thickness in our study is actually related to the nutrition of the hens. Omar et al. (2014) did not detect any significant changes in egg weight and yolk share in eggs after using fish oil in the mixtures for laying hens, which is in agreement with the results reported by Ceylan et al. (2011). Jin et al. (2011) confirmed that egg shell weight and albumen weight decreased during storage $(P$ $<0.001)$, as was the case in our study. Grobas et al. (2001) and Güclü et al. (2008) indicated that different oils can affect egg weight. In our study, this property was affected by the duration of egg storage $(P<0.01)$.

Jin et al. (2011) observed brighter egg yolks in eggs stored for 28 days compared to those stored for 7 days in the refrigerator $(P<0.003)$. These results are consistent with the observations of Fasiangova and Borilova (2017), as well as those of Kralik et al. (2017). Scheideler et al. (2010) stated that the $\mathrm{pH}$ values of fresh albumen is in the range of 7.68.5 and for yolks around 6.0, which increase during egg storage to $>9$ in the albumen and up to 6.9 in the yolk. The albumen becomes less dense after the hydrolysis of ovomucin, which affects the height of albumen (indicated by $\mathrm{HU}$ ) used in the freshness display of eggs. Batkowska et al. (2016) suggested that egg storage affects the increase in egg air space, egg weight loss, and increase in the albumen $\mathrm{pH}$ value. They showed that the $\mathrm{pH}$ of yolks ranged from 6.57 to 6.75 after 28 days of storage in the refrigerator, which is similar to the $\mathrm{pH}$ values of 6.09-6.31 observed in this study. Papas et al. (2005) and Silversides and Scott (2001) indicated that HU is maximum after egg oviposition and decreases during storage. The results of this study, as well as those of Batkowska et al. (2016), are in agreement with the results of the aforementioned authors. According to Rakonjac et al. (2014), lysozyme, ovomucoid, and cystatin are biologically active proteins in the albumen and affect the preservation of egg freshness.

Ao et al. (2015) used 1\%, 2\%, and 3\% microalgae (All-GRich $^{\mathrm{TM}}$, Alltech Inc.) in the mixtures for laying hens. The content of DHA increased linearly with the increase in the proportion of microalgae in the mixture. The authors observed that $248 \mathrm{mg}$ DHA was present in the eggs of the control group, whereas $509 \mathrm{mg}, 717 \mathrm{mg}$, and $776 \mathrm{mg} / 100 \mathrm{~g}$ 
DHA was present in the egg yolk of the three experimental groups. Ao et al. (2015) concluded that addition of microalgae in the mixture for laying hens can enable the production of DHA-enriched eggs without any negative effect on their quality. Ceylan et al. (2011) fed laying hens with mixtures containing $1.5 \%$ and $3.0 \%$ sunflower oil, fish oil, flaxseed oil, and canola oil. The eggs from hens that were fed sunflower oil had lighter egg yolk color than the other egg yolks. ALA content increased after adding 3\% flaxseed oil and canola oil in the mixtures for laying hens, and the addition of fish oil increased the deposition of DHA in the egg yolks. Ceylan et al. (2011) consider that the nutritional quality of a product can be evaluated by the ALA:LA and n6/n-3 PUFA ratios. ALA can be desaturated and elongated to DHA in the liver of laying hens. ALA from flaxseed oil can act as a DHA precursor if the feed does not contain sufficient DHA (Da Silva et al., 2009). Kralik et al. (2008), Ceylan et al. (2011), and Nain et al. (2012) concluded that the fatty acid profile may be modified by adding selected feed (oils) rich in n-3 PUFA and determined the following order for decreasing the n-6/n-3 PUFA ratio: flaxseed oil $>$ fish oil $>$ canola oil $>$ sunflower oil. Janječić et al. (2018) added 0.5 and $1.0 \% \mathrm{~S}$. limacinum microalgae in the mixture for laying hens (A control, B 0.5\% microalgae, and C 1.0\% microalgae). The addition of 0.5 and $1.0 \%$ microalgae resulted in higher levels of n-3 PUFA in the eggs (B $1.23 \%, \mathrm{C}$ $1.56 \%$, A $0.82 \%$ ) and the $n-6 / n-3$ PUFA ratios were 14.89 : 22.29 and 11.45: 22.29, respectively. These results are not consistent with the results of our and other studies. Kaewsutas et al. (2016) investigated the effect of adding microalgae and fish oil on the DHA content in eggs. Laying hens were fed with the following mixtures: control group, $4 \%$ fish oil; $1^{\text {st }}$ experimental group, $1 \%$ microalgae; $2^{\text {nd }}$ experimental group, $2 \%$ microalgae. Higher DHA content was observed in egg yolks from hens fed $1 \%$ and $2 \%$ microalgae than the control eggs from hens fed $4 \%$ fish oil $(P<0.05)$. Feeding with $2 \%$ microalgae in the mixture resulted in DHA content of 114 mg/egg, and the n-6/n-3 PUFA ratio was reduced to optimal limits. European food safety experts (International Life Sciences, 2010) believe that consumption of $250 \mathrm{mg} /$ day $\mathrm{EPA}+\mathrm{DHA}$ is sufficient for the daily requirement. According to EU Directives and the EPA and DHA content, eggs produced in E1 and E2 groups can be considered high source of omega-3 fatty acids.

Compared to the control group, Dunn-Hurrocks et al. (2011) and Kralik et al. (2012) observed higher lipid oxidation intensity in eggs when laying hens were fed fish oil or canola oil, which was similar to our observations made during egg storage. Gajčević et al. (2009) and Mohiti-Asli et al. (2008) observed that the addition of antioxidants in food decelerates oxidation and increases the freshness persistence of eggs.

The results of our study on the use of different concentrations $(0.5 \%$ and $0.75 \%)$ of fish oil and microalgae $S$. limacinum, and their comparison to the results obtained after using the soybean oil control, showed that lower concentrations of fish oil and $S$. limacinum are sufficient for enrich- ment of eggs with n-3 PUFA. We also observed that feeding treatments do not impair the quality of eggs that, according to the indicators, remain within the optimal limits for table eggs. Furthermore, we noticed that the addition of microalgae to the feed for laying hens positively affected yolk color, which might be because of the carotenoids content in microalgae. In future work related to this topic, it is necessary to carry out research regarding the influence of these feeding treatments on the sensory properties of eggs.

\section{Acknowledgments}

This study was supported by the European Structural and Investment Funds grant for the Croatian National Scientific Center of Excellence for Personalized Health Care (grant \#KK.01.1.1.01.0010) and by the Ministry of Science and Education of the Republic of Croatia.

\section{Conflicts of Interest}

The authors declare no conflict of interest.

\section{References}

Ao ZT, Macalintal LM, Paul MA, Pescatore AJ, Cantor AH, Ford MJ, Timmons B and Dawson KA. Effects of supplementing microalgae in laying hen diets on productive performance, fatty-acid profile, and oxidative stability of eggs. Journal of Applied Poultry Research, 24: 394-400. 2015.

Batkowska J, Brodacki A and Gryzinska, M. Effects of laying hen system and storage on egg quality. European Poultry Science, 80, 2016.DOI: 10.1399/eps.2016.158

Cachaldora P, García-Rebollar P, Alvarez C, DE Blas JC and Méndez J. Effect of type and level of fish oil supplementation on yolk fat composition and n-3 fatty acids retention efficiency in laying hens. British Poultry Science, 47: 43-49. 2006.

Ceylan N, Ciftci I, Mizrak C, Kahraman Z and Efil H. Influence of different oil sources on performance and fatty acid profile of egg yolk in laying hens. Journal of Animal and Feed Sciences, 20: 71-83. 2011.

Christie WW. A simple procedure for rapid transmethylation of glycerolipids and cholesteryl esters. Journal of Lipid Research, 23: 1072-1075. 1982.

Commission Regulation (EU) No 116/2010 of 9 February 2010 amending Regulation (EC) No 1924/2006 of the European Parliament and of the Council with regard to the list of nutrition claims. Official Journal of the European Commission, 37: 1618. 2010.

da Silva WA, Naiverti Elias AH, Aricetti JA, Sakamoto MI, Murakami AE, Marques Gomes ST, Visentainer JV, de Souza NE and Matsushita M. Quail egg yolk (Coturnixcoturnix japonica) enriched with omega-3 fatty acids. LWT - Food Science and Technology, 42: 660-663. 2009.

Duman M, Şekeroğlu A, Yıldırım A, Eleroğlu H and Camcı Ö. Relation between egg shape index and egg quality characteristics. European Poultry Science, 80, 2016. DOI: 10.1399/eps. 2016.117

Dunn-Hurrocks S, Pichardo-Fuchs M, Lee J, Ruiz-Feria C, Creger C, Hyatt D, Stringfellow K, Sanchez M and Farnell M. Effect of omega-3 enriched layer rations on egg quality. International Journal of Poultry Science, 10: 8-11. 2011.

Fasiangova M and Borilova D. Impact of Se supplementation on the oxidation stability of eggs. World's Poultry Science Journal, 
73: 175-184. 2017.

Folch JM, Lees M and Sloane-Stanley GH. A simple method for the isolation and purification of total lipids from animal tissues. Journal of Biological Chemistry, 226: 495-509. 1957.

Fraeye I, Bruneel C, Lemahieu C, Buyse J, Muylaert K and Foubert I. Dietary enrichment of eggs with omega-3 fatty acids: A review. Food Research International, 48: 961-969. 2012.

Gajčević Z, Kralik, G, Has-Schön E and Pavić V. Effects of organic selenium supplemented to layer diet on table egg freshness and selenium content. Italian Journal of Animal Science, 8: 189199. 2009.

Grobas D, Mendez J, Lazaros J, Blas CD, Mateos GG and De BC. Influence of source of fat added to diet on performance and fatty acid composition of eggs yolks of two strains of laying hens. Poultry Science, 80: 1171-1179. 2001.

Güclü BK, Uyanik F and Iscan K.M. Effects of dietary oil sources on egg quality, fatty acid composition of eggs and blood lipids in laying quail. South African Journal of Animal Science, 38: 91-100. 2008.

Ikegwu TM, Balogu VT, Balogu DO, Kolo SI and Babatunde J. Physical Properties of Hen's Egg. Journal of Foods, Natural and Life Sciences, 1: 16-23. 2016.

Janječić Z, Bedeković D, Kljak K, Gorupić M, Musulin M. Effects of supplementing microalgae in laying hen diets on productive performance, color and content of carotenoids and fatty-acid profile of yolks, in: Conference Information and Proceedings of The XVth European Poultry Conference, Dubrovnik, Croatia ed. by Prukner-Radovčić E and Medić H. Croatian Branch of the World's Poultry Science Association, Dubrovnik, pp. 54, 2018.

Jin YH, Lee KT, Lee WI and Han YK. Effects of storage temperature and time on the quality of eggs from laying hens and peak production. Asian-Australasian Journal of Animal Sciences, 24: 279-284. 2011.

Kaewsutas M, Sarikaphuti A, Nararatwanchai T, Sittiprapaporn P and Patchance P. The effects of dietary microalgae (Schizochytrium spp.) and fish oil in layers on docosahexaenoic acid omega-3 enrichment of the eggs. Journal of Applied Animal Nutrition, 4: 1-6. 2016.

Kralik G, Bogut I, Škrtić Z and Gajčević Z. Effect of preparation rich in omega-3 acids on the production and quality of eggs. In Proceedings of the XVII European Symposium on the Quality of Poultry Meat and XI European Symposium on the Quality of Eggs and Egg Products, Golden Tulip Park hotel Doorwerth, Doorwerth, Netherlands, 23-26 May 2005 (pp. 122-127). World's Poultry Science Association (WPSA), 2005.

Kralik G, Kralik Z, Grčević M and Škrtić Z. Obogaćivanje peradarskih proizvoda funkcionalnim sastojcima. Poljoprivreda, 18: 52-59. 2012.

Kralik G, Kralik Z, Grčević M, Kralik I and Hanžek D. The effect of feeding laying hen conventional and omega-3 enriched diet on fatty acid profiles in egg yolk lipids. Journal of Agricultural Science and Technology B, 5: 506-511. 2015.

Kralik G, Škrtić Z, Suchy P, Strakova E and Gajcevic Z. Feeding fish oil and linseed oil to laying hens to increase the n-3 PUFA of egg yolk. ActaVeterinaria (Brno), 77: 561-568. 2008.

Kralik G,Bogut I, Škrtić Z and Gajčević Z. Effect of preparation rich in omega-3 acids on the production and quality of eggs. In: Proceedings of $\mathrm{XI}^{\text {th }}$ European Symposium on the Quality of
Eggs and Egg Products (CD), 23-26 May 2005, Doorwerth, The Netherlands, p. 122-127. 2005.

Kralik Z, Grčević M, Kralik G, Hanžek D and Zelić A. Quality of table eggs on the Croatian market. Poljoprivreda, 23: 63-68. 2017.

Mohiti-Asli M, Shariatmadari F, Lotfollahian H and Mazuji MT. Effects of supplementing layer hen diets with selenium and vitamin $\mathrm{E}$ on egg quality, lipid oxidation and fatty acid composition during storage. Canadian Journal of Animal Science, 88: 475-483. 2008.

Nain S, Rednema RA, Korver DR and Zuidhof MJ. Characterization of the n-3 polyunsaturated fatty acid enrichment in laying hens fed an extruded flax enrichment source. Poultry Science, 91: 1720-1732. 2012.

Narodne novine (Official Gazette of the Republic of Croatia). Rulebook on egg quality, 115/2006.

Omar, AS, Ramadan NA, Bahakaim ASA, Osman SMH and Malak NYA. Effect of using different levels of fish oil, linseed oil and other combination in layer diets on egg omega 3 enrichment. Journal of Animal and Poultry Production, 5: 759-774. 2014.

Pappas AC, Acamovic T, Sparks, NHC, Surai PF and Mc Devitt RM. Effects of supplementing broiler breeder diets with organic selenium and polyunsaturated fatty acids on egg quality during storage. Poultry Science, 84: 865-874. 2005.

Rakonjac S, Bogosavljevic-Boskovic S, Pavlovski Z, Skrbic Z., Doskovic V., Petrovic MD and Petricevic V. Laying hen rearing systems: A review of major production results and egg quality traits. World's Poultry Science Journal, 70: 93-104. 2014.

Samli HE, Agma A and Senkoylu N. Effects of storage time and temperature on egg quality in old laying hens. Journal of Applied Poultry Research, 14: 548-553. 2005.

Scheideler SE, Weber P and Monsalve D. Supplemental vitamin E and Se effects on egg production, egg quality, and egg deposition of $\alpha$-tocopherol and Se. Journal of Applied Poultry Research, 19: 354-360. 2010.

Shin D, Narciso-Gaytán C, Regenstein JM and Sánchez-Plata MX. Effect of various refrigeration temperatures on quality of shell eggs. Journal of the Science of Food and Agriculture, 92: 1341-1345. 2012.

Silversides FG and Scott TA. Effect of storage and layer age on quality of eggs from two lines of hens. Poultry Science, 80: 1240-1245. 2001.

Siro I, Kapolna E, Kapolna B and Lugasi A. Functional Food. Product Development, marketing and consumer acceptance - A review. Appetite, 31: 456-467. 2008.

Statistica for Windows v.13.3. (Stat Soft Inc., 2017)

Surai PF and Sparks NHC. Designer eggs: from improvement of egg composition to functional food. Trends in Food Science \& Technology, 12: 7-16. 2001.

Wolc A, Arango J, Settar P, O'Sullivan NP, Olori VE, White IMS, Hill WG and Dekkers JCM. Genetic parameters of egg defects and egg quality in layer chickens. Poultry Science, 91: 12921298. 2012.

Zotte AD, Andrighetto I, Giacccone V and Marcehesini G. Dietary enrichment of $n$-3 PUFA for laying hens: effect of different sources on production, composition and quality of eggs. Animal Science Papers and Reports, 33: 411-424. 2015. 